\title{
Historical Sociological Approach in International Relations
}

\author{
By Bihter Çelikdemir ${ }^{*}$
}

\begin{abstract}
The aim of this study is to underline the importance of historical sociology for the discipline of International Relations and to suggest this research approach for the analysis of nation-state-building processes. Mainstream theories of International Relations, like neorealism and neoliberalism, argue that state behavior is determined by the international system (or structure). Since these theories attribute to the international system a key and determining role to understand state actions without having a state theory of their own, they fail to understand the transformations of the state throughout the history. In this article, it is argued that the discipline of International Relations should analyze the state and develop a theory of it. It is also argued that the way of achieving this goal is to historicize the state with a historical sociological approach.
\end{abstract}

Keywords: Historical Sociology, International Relations, International System, Social Relations, Nation-State, Capitalism.

\section{Introduction}

With the establishment of the discipline of International Relations as a separate field of social sciences, history and sociology are treated as unrelated research areas, since the discipline relies upon the distinction between internalexternal or local-international. Analyzing the local one - in other words the state and the society -is considered as the study field of sociology and history, whereas examining the international one is seen as the mission of International Relations (Yalvaç 1991, 2013). Mainstream theories of International Relations treat history as a material storage for the validation of their theories. This has resulted in -as Hobden and Hobson put it- "chronofetishism" and "tempocentrism": these theories take an approach that makes the current order absolute, ignoring historical processes/transformations (Hobden and Hobson 2002: 5-7). The discipline's dominant paradigms disconnect the discourse of International Relations from both world history and relations of production. By placing the state at the center of analysis, they exclude social classes and class struggles from the discipline (Hobden 1998, 1999). That is precisely why the discipline -having developed ahistorically- is dominated by neorealist approach (Hobden and Hobson 2002). Moreover, it is also very contradictory that neo-realism, a theory that considers the state as the principal actor, does not have a state theory of its own and does not attribute any role to the state in affecting the international system (Hobson 1998).

From this problematic background, this article argues the importance of

${ }^{*} \mathrm{PhD}$ Candidate, Ankara University, Turkey. 
historical sociology for the discipline of International Relations and its efficacy for the analysis of nation-state-building processes. Mainstream theories of International Relations, like neo-realism and neo-liberalism, argue that state behavior is determined by the international system or structure. Hence, they fail to understand the state's transformations throughout history. This article argues the discipline of International Relations should analyze and develop a theory of the state, and that the way of achieving this is to adopt a historical sociological approach. This article provides a case study using historical sociology as an alternative method for examining Germany's nation-state-building process. It is suggested that historical sociology be employed for further studies in this research area.

\section{Historical Sociology and International Relations}

There are various approaches among international historical sociology studies. This article mentions two of these approaches. The first one is the uneven and combined development model and the other one is political Marxism. Rosenberg first brought historical sociology into international relations in his 2006 essay, "Why is there no international historical sociology?" (Rosenberg 2006). He wanted to develop a historical materialist theory of international relations. Rosenberg argues the concept of the "international" originated historically in Trotsky's theory of an uneven and combined development model. This theory of uneven and combined development tries to explain it in the international context rather than looking at developments in a single society. The concept of development, used in the model, does not mean a one-way process where all states will go through similar stages, as the modernization theories suggest. Rather, development is seen as a dimension of uneven and combined social change. Studies have been carried out on the relationship between capitalism and emergence of nation states, based on this conceptual model.

Political Marxists have developed approaches that prioritize class struggle and relations of production. Teschke, the most important representative of political Marxism in the discipline of International Relations, argues that modes of social relations of production are the starting point for understanding the structure of and change in international relations (Teschke 2003). According to Teschke, tracking the transformation in the relations of production leads to the formation of state. Therefore, he examines both the role of social property relations and international dynamics during the capitalist transition in Europe and how these two developments affect each other. According to Teschke, modern states are shaped by both the existing capitalist transformation in social property relations and the geopolitical context. In every single state experience, social property relations are the most significant factor for understanding different transition processes. The expansion of capitalist property relations from England forms the geopolitical context which Teschke mentions. In his words:

"While the endogenous development of capitalism was unique to England, its expansion was not transnational but a geopolitically mediated process that transformed the dynastic states on the continent into modern states in a long-term 
process of geopolitically combined and socio-politically uneven development. In this process, international relations in nineteenth-century Europe were largely about the management of the modernizing pressure created by the new British state/society complex, which puts its European neighbours at a competitive and economic comparative disadvantage. This forced state classes to design counterstrategies that led to a series of "revolutions from above" - the introduction of capitalism." (Teschke 2003: 11-12)

International historical sociology, as summarized so far, is an attempt to historicize the state. It is argued that mainstream theories of International Relations ignore relations of production and capitalism while examining state relations. At this point, historical sociology establishes a mutual relationship between internal society and the international system. In this sense, international historical sociology re-conceptualizes state. Historical sociological studies in the discipline of International Relations explore internal and external social forces that play a role in the formation of the state system. Accordingly, an historical sociological approach consists of two integrative issues: the transformative effect and pressure of the international system on social class relations, and the role of social relations in the transformation of production relations and, gradually, in the formation of the state (Halliday 2002). The traditional approach, treating the state as a function of the international system, is thus abandoned. This new approach tries to understand state within the interrelation of production relations, social forces and international system (Cox 1981). In line with historical sociology, there is no single model or social structure in the development of societies; historical change always takes place depending on the society's concrete conditions. The method of historicizing state involves investigating it in the context of a capitalist transformation of the modes of production, as well as in relation to the expanding nature of the international capitalist system.

\section{The State as a Product of the Transition from Feudalism to Capitalism}

The question of the emergence of the first absolutist nation states in Western Europe has developed within an old debate on the origins and evolution of capitalism in Europe. The argument that the European states system and capitalism is linked closely depends on the essential unity of politics and economics. The socalled "transition debate" gives a theoretical background on the interdependence of the emergence of capitalism and the states system in Western Europe (Sweezy and Dobb 1950, Takahashi 1952, Dobb and Sweezy 1953, Hilton and Hill 1953, Ashton and Philpin 1987, Lachmann 1989). This debate on the transition from feudalism to capitalism has made major contributions to explain both the class structure and dynamics of pre-capitalist societies and the elements of the transition itself. Changes in the mode of production and class relations interact together and determine each other. The formation of a political unit and the change in the relations of production are intertwined. Another important contribution of this debate is that it has established a close relationship between social relations and class structure before capitalism -in the feudal period- and the organization of 
political power (Brenner 1987a, Brenner 1987b). Finally, this debate does not ignore the internationalization of modes of production in explaining the emergence of capitalism, stating that capitalism was first developed in England and that the birth of British capitalism was a factor profoundly affecting the transition to capitalism in other parts of Europe. In other words, this debate considers the uneven character of capitalist development which plays an important role in determining the transition process in continental Europe.

Political Marxists like Wood, Brenner, and Teschke define capitalism as a social order based upon social property relations whereby direct producers are forced to sell their labor to the owners of the means of production as a commodity at the market. In this definition, the logic of production and social class relations are emphasized. In capitalist relations of production, unlike the feudal one, the exploitation of labor is not achieved directly by physical means of force or violence. In feudal system, economic and political exploitation are two sides of the same coin (Anderson, 1974). By contrast, capitalism represents a rupture from feudal relations of production, since in capitalist system of production, the economic and political exploitation areas seems to be separated. This leads us to the relationship between capitalism and the state. The historical role of the state is important in transforming the economic and political structure of feudalism into the pure economic exploitation inherent in capitalism. In capitalism, although state and market are directly linked, they appear structurally as two separate areas (Brenner 1987a). Tracing the transformation of the feudal relations of production into the capitalist one leads us to the formation of the state. In Wood's words:

\begin{abstract}
"Just as the separation of the 'political' and the 'economic' in capitalism ended the contestation of sovereignty among competing sites of extra-economic power, so it helped to fix the state's territorial borders by detaching them from the fluctuating fortunes of personal property and dynastic connections. There were, to sum up, two sides to the historical relation between capitalism and the nation state. On the one hand, that state was not itself produced by capitalism. The 'modern' state, together with 'modern' conceptions of territoriality and sovereignty, emerged out of social relations that had nothing to do with capitalism, in the tensions between parcellized sovereignties and centralizing monarchies. On the other hand, the rise of capitalism, which took place in the context of a rising nation state, brought that state to fruition- or, to put it more precisely, the particular form of English state formation belonged to the same process that brought about capitalism. The transformation of politically constituted property into capitalist property was at the same time, and inseparably, a transformation of the state". (Wood 2002: 174175)
\end{abstract}

\title{
An Example of Historical Sociological Method: The German Empire
}

This study argues for an historical sociological approach for the analysis of nation-state-building processes. Provided here is an example of this approach in dealing with the first German nation-state, i.e. the German Empire. Following an analysis of the dominant paradigm in the German historiography, a historical sociological approach will be outlined for future studies. 
Historians at the University of Bielefeld, who became renowned as the Bielefeld School, founded West Germany's critical social history in the 1960s and 1970s, leading to a paradigm shift in German historiography (Fletcher 1984). Hans-Ulrich Wehler and Jürgen Kocka, two important representatives of the Bielefeld School, pioneered an historical thesis called "Sonderweg," meaning special path. ${ }^{1}$ This thesis compares of historical developments in Germany with those in Britain and France. At the center of the Sonderweg thesis is the claim that the dominance of the great landowners (Junker class) persisted in Germany even after the feudal period (Rosenberg 1943, 1944). According to this thesis, German history deviated from the history of Britain and France because in Germany the bourgeoisie revolution failed in 1848 to terminate Junker, i.e., aristocratic landowner class, rule. In this context, Wehler claims the "feudalization" of the German bourgeoisie due to the failed revolution in 1848 (Wehler 1981: 478-487). Kocka, like Wehler, argues that German history has two significant distinctions from other Western European states. The first one is that it underwent a late and from-above nationalization process (not a bourgeois revolution from below). The second difference is that the state structure was organized along bureaucratic and authoritarian (not liberal) lines due to dominance by the Junker class (Kocka 1988). Despite these differences, the feudal relations of production transformed into capitalist ones, but without the redistribution of political power, that is, without the strengthening of the bourgeoisie against the land nobles.

While the Sonderweg thesis is an important paradigm in German historiography, it can still be criticized on some points. The thesis is based on the comparison of the developments in Germany with the ones in Britain and France. However, each society has specific ways of development that are shaped by its own social dynamics. The Sonderweg thesis expresses a modernist-positivist approach in the sense that it contains the assumption that there is a "normal" or "standard" way of modernization to be followed (Blackbourn and Eley 1984). In this sense, the most important shortcoming of the Sonderweg approach is that it does not include the transformation of the relations of production. The thesis leaves in the shadow the social class conflicts and transformations in the modes of production. However, as claimed in this article, there is a direct and reciprocal relationship between state-building process and capitalization of relations of production. The mistake of seeing capitalism as the historical mission of the bourgeois class is frequently repeated in the literature (Gill 2008). It is important to remember that, while the transition to capitalism features a transformation in the relations of production, this process need not occur entirely (if at all) under the leadership of the bourgeoisie. Even in Britain, the first capitalist state, the capitalist transformation in the relations of production began with agricultural capitalism, followed by industrial capitalism (Blackbourn and Eley 1984). Capitalism indicates a social transformation in the relations of production, but the landed nobility can also be capitalist. In Germany, the Junker class - the old feudal landowners - became the capitalist producers and merchants of their time (Rosenberg 1958, Rosenberg 1969). The absence of a bourgeois revolution did not

${ }^{1}$ They founded the Zentrum für Interdiziplinaere Forschung in Bielefeld in 1968 and began to publish the Geschichte und Gesellschaft: Zeitschrift für Historische Sozialwissenschaft in 1975. 
mean the absence of capitalist transformation.

With a historical sociological background, an alternative approach to German history can rely upon two main pillars. First, internal social- developments play a key role in the German case. The formation of capitalism in various countries is closely linked to the previous social structures, i.e. the internal density and organization of the existing feudal economy. The analysis of class structures and property relations in the feudal period is thus important. In terms of different historical conditions, capitalist transformation followed a different path in Germany than in France or Britain. Because this dissimilarity resulted from different class structures and property relations during the feudal era, it is crucial to examine the feudal class structures and property. Different property systems give rise to different processes of political accumulation and in turn determine organization of the state. In this way, different transitions to capitalism in Europe can be explained.

Second, the absolutist state structure must also be examined as the political unit of the transition process. The Prussian Kingdom was the key political unit in German history during the dissolution phase of feudalism and the subsequent transition period to capitalism (Blanning 1986, Gillis 1968). As the historical social origins of the German Empire can be traced back to the east of Elbe River and Prussian Kingdom, in order to understand the authenticity of the Prussian absolutist state and its expansion, the feudal period that precedes this structure must also be considered. In this way, the formation, development, and mutual interaction of social classes in establishing the relations of production can be discovered.

Furthermore, external factors also play a significant role. Studying the historical social foundations of the first united German state also means examining the transformation process from feudalism to capitalism in the region as a whole. The establishment of German political unity can only be comprehended within the context of the developments in Western Europe during the same period, i.e. the transformation of relations of production. England's transition to capitalism, as the first capitalist state, was about internal pressures, namely class struggles and change in the modes of production. But the experience is different for the ones in the second wave transition to capitalism, including that which occurred in Germany. Military and commercial competition put pressure on each of these states after the mid- $19^{\text {th }}$ century, as the uneven and combined development model suggests (Teschke 2003). Because of the rapid capitalization of other economies external pressures- the transition to capitalism was achieved primarily by revolutions from above. In Germany, feudal social and production relations were replaced by the capitalist ones, not through class struggles but through the pressures of a capitalizing European economy guided (from above) by the hands of the ruling class (Mitchell 1977, Taylor 2001).

\section{Conclusion}

International historical sociology rejects approaches with single development models or a single social structure. Instead, it defines two main macro processes: 
state formation and capitalism. If we are to examine any social process, it should be examined in relation to these two macro processes. Relations of production and class structures play a very crucial role in explaining the transition from feudalism to capitalism and the construction of nation states. At the same time, these factors should be considered together with pressures imposed by the international system on each state to participate in the capitalist world economy. In this wise, it is possible to have a holistic explanation.

This article argues that historical sociology has contributed to the discipline of International Relations in many ways, but most importantly in putting social relations and transformations onto the research agenda. International historical sociology, by moving away from a static understanding of history and an unchanging international structure, has developed an international understanding based on social relations. Furthermore, key concepts of the discipline, such as state and states system, have been put in an historical context.

This article has shown the value of utilizing an historical sociological approach through the case study of German nation state building. The evaluation of the Sonderweg thesis points out the importance of this research method for the study of history. It is important to place the transformations in the production relations at the center of the analysis. In line with the transition debate, the German Empire can be considered more as a transformation than a structure established in January 1871. Political unification can be understood as the political reflection of the change -or transformation- in the modes of production. To understand the meaning of historical processes, it is necessary to place them in a long historical perspective. In the same way, to understand the German Union, it is suggested to look at the transformation between the two modes of production, namely from feudalism to capitalism. Nation state building processes, i.e., political transformation depend upon structural transformation in the economy.

\section{References}

Anderson P (1974) Passages from Antiquity to Feudalism, London: New Left Books.

Ashton TH, Philpin CHE (ed) (1987) The Brenner Debate: Agrarian Class Structure and Economic Development in Pre-industrial Europe. Cambridge University Press.

Blackbourn D, Eley G (1984) The Peculiarities of German History: Bourgeois Society and Politics in Nineteenth-Century Germany. Oxford und New York.

Blanning TCW (1986) The Death and Transfiguration of Prussia. The Historical Journal 29(2), 433-459.

Brenner R (1987a) Agrarian Class Structure and Economic Development in Pre-Industrial Europe. In The Brenner Debate, Ashton and Philpin (ed), 10-63. Cambridge University Press.

Brenner R (1987b) The Agrarian Roots of European Capitalism, In The Brenner Debate, Ashton and Philpin (ed), 213-327. Cambridge University Press.

Cox RW (1981) Social Forces, States and World Orders: Beyond International Relations Theory. Millennium: Journal of International Studies 10(2): 126-155.

Dobb M, Sweezy PW (1953) Comments on Takahashi's Transition From Feudalism to Capitalism. Science \& Society 17(2): 155-164.

Fletcher R (1984) Recent Developments in West German Historiography: The Bielefeld 
School and its Critics. German Studies Review 7(3): 451-480.

Gill G (2008) Bourgeoisie, State and Democracy. New York: Oxford University Press,.

Gillis JR (1968) Aristocracy and Bureaucracy in Nineteenth-Century Prussia. Past \& Present, 41: 105-129.

Halliday F (2002) For an International Sociology. In Historical Sociology of International Relations, S Hobden, JM Hobson, 244-264. Cambridge University Press.

Hilton RH, Hill C (1953) The Transition From Feudalism to Capitalism. Science \& Society 17(4): 340-351.

Hobden S, Hobson JM (2002) Historical Sociology of International Relations. Cambridge University Press.

Hobden S (1998) International Relations and Historical Sociology. New York: Routledge.

Hobden S (1999) Theorising the International System: Perspectives from Historical Sociology. Review of International Studies 25(2): 257-7 1.

Hobson J M (1998) The Historical Sociology of the State and the State of Historical Sociology in International Relations. Review of International Political Economy 5(2): 284-320.

Kocka J (1988) German History before Hitler: The Debate about the German 'Sonderweg. Journal of Contemporary History 23(1): 3-16.

Lachmann R (1989) Origins of Capitalism in Western Europe: Economic and Political Aspects. Annual Review of Sociology 15: 47-72.

Mitchell A (1977) Bonapartism as a Model for Bismarckian Politics. Journal of Modern History 49(2): 181-199.

Rosenberg J (2006) Why is There No International Historical Sociology? European Journal of International Relations 12(3): 307-340.

Rosenberg H (1958) Bureaucracy, Aristocracy and Autocracy. The Prussian Experience 1616-1815. Cambridge.

Rosenberg H (1969) Probleme der deutschen Sozialgeschichte. Frankfurt: Suhrkamp Verlag.

Rosenberg H (1943) The Rise of the Junkers in Brandenburg-Prussia, 1410-1653, part 1. The American Historical Review 49(1): 1-22.

Rosenberg H (1944) The Rise of the Junkers in Brandenburg-Prussia, 1410-1653, part 2. The American Historical Review 49(2): 228-242.

Sweezy PM, Dobb M (1950) The Transformation From Feudalism to Capitalism, Science \& Society 14(2): 134-167.

Takahashi K (1952) The Transition from Feudalism to Capitalism: A Contribution to the Sweezy-Dobb Controversy. Science \& Society 16(4): 313-345.

Taylor AJP (2001) The Course of German History: A Survey of the Development of Germany since 1815. New York: Routledge.

Teschke B (2003) The Myth of 1648. Class, Geopolitics, and the Making of Modern International Relations. Verso.

Wehler HU (1981) Deutscher Sonderweg oder allgemeine Probleme des westlichen Kapitalismus. Merkur: 478-487.

Wood EM (2002) The Origin of Capitalism: A Longer View. Verso.

Yalvaç F (2013) Tarihsel Sosyoloji ve Uluslararası İlişkiler: Jeopolitik, Kapitalizm ve Devletler Sistemi. Uluslararası Illişkiler 10(38): 3-28.

Yalvaç F (1991) The Sociology of the State and the Sociology of International Relations. In State and Society in International Relations, M. Banks, M Shaw (eds), 93-114. Hemel Hempstead: Harvester. 